\title{
Model Pendidikan Karakter dan Kewirausahaan Berbasis Etnopedagogis di Sekolah Dasar Kampung Cikondang
}

\author{
1) LAKSMI DEWI, 2) AHMAD YANI, 3) ASEP DUDI SUHARDINI \\ ${ }^{1}$ Fakultas IImu Pendidikan, UPI ; ${ }^{2}$ Fakultas Pendidikan IImu Pengetahuan Sosial, UPI \\ ${ }^{3}$ Fakultas Tarbiyah dan Keguruan, Universitas Islam Bandung \\ email: ${ }^{1)}$ laksmi@upi.edu, 2) ahmadyani@upi.edu ${ }^{3)}$ asep.abushaffa@gmail.com
}

\begin{abstract}
The purpose of this research was developing a model of etnopedagogic-based character and entrepreneurship education in elementary school. The research location was indigenous village named Cikondang that sites in South of Bandung. The research was begun by identifying the local culture and also character and entrepreneurship values in local community. Furthermore, it developed learning models and learning tools within local wisdom-based character and entrepreneurial values. The research method was research and development method. The result of the trial showed that the model was effectively implemented. The learners felt happy dan enthusistic about carrying out various learning activiteis during the learning prosess. However, its overall implementation in the school education system need more of time that any of these values could be integrated in the behavior of all member of the school.
\end{abstract}

Keywords: character, entrepreneurship, etnopedagogic

\begin{abstract}
Abstrak. Tujuan penelitian ini adalah mengembangkan model pendidikan karakter dan kewirausahaan yang berbasis etnopedagogis di sekolah dasar. Lokasi penelitian di Lingkungan Kampung Adat Cikondang di Kabupaten Bandung. Penelitian diawali dengan mengidentifikasi budaya lokal dan makna dari nilai-nilai karakter bangsa dan kewirausahaan yang ada di masyarakat setempat. Selanjutnya mengembangkan model pembelajaran dan perangkat pembelajaran yang memiliki muatan karakter bangsa dan kewirausahaan berbasis kearifan lokal. Metode yang digunakan dalam penelitian ini adalah penelitian dan pengembangan. Hasil ujicoba menunjukkan bahwa model tersebut efektif dilaksanakan, terbukti saat proses pembelajaran berlangsung peserta didik merasa senang dan antusias melaksanakan berbagai aktivitas dalam pembelajaran. Namun demikian untuk penerapan secara menyeluruh pada sistem pendidikan di sekolah masih memerlukan waktu yang cukup panjang agar setiap nilai-nilai tersebut dapat terintegrasi dalam perilaku semua warga sekolah.
\end{abstract}

Kata kunci: karakter, kewirausahaan, etnopedagogis

\section{Pendahuluan}

Pengembangan Pendidikan Karakter dan Kewirausahaan telah dimulai sejak 2010, yaitu sejak diterbitkan Buku Pedoman Pendidikan Budaya dan Karakter Bangsa sebagai salah satu hasil dari program 100 hari yang diamanahkan kepada Badan Penelitian dan Pengembangan Kementerian Pendidikan Nasional Kabinet Bersatu II. Latar belakang mendesaknya pendidikan karakter dan kewirausahaan antara lain semakin merosotnya nilai, norma, dan karakter bangsa. Untuk itu, pendidikan karakter dan kewirausahaan merupakan bekal penting yang harus dimiliki oleh setiap insan generasi muda penerus bangsa, agar dapat bertahan dari terpaan berbagai masalah yang akan menghadangnya.

Saat ini, tidak sedikit masalah-masalah yang terjadi di lingkungan sekolah berkaitan dengan rendahnya nilai karakter. Sampai saat ini kita masih mendengar adanya kecurangan dalam Ujian Nasional, perkelahian antar pelajar, kekerasan pada anak (bullying), penyalahgunaan narkoba, korupsi, dan

Received: 8 Juli 2015, Revision: 10 Oktober 2015, Accepted: 23 Desember 2015

Print ISSN: 0215-8175; Online ISSN: 2303-2499. Copyright@2015. Published by Pusat Penerbitan Universitas (P2U) LPPM Unisba Terakreditasi SK Kemendikbud, No.040/P/2014, berlaku 18-02-2014 s.d 18-02-2019 
berbagai kerusuhan sosial. Sebuah penelitian yang dilakukan oleh LSM Plan Internasional dan International Center for Research on Woman (ICRW) pada bulan Maret 2015 menunjukkan fakta bahwa terdapat $84 \%$ anak di Indonesia mengalami kekerasan di sekolah (liputan6.com). Tahun 2009 di bulan Maret Direktorat narkoba Polda Metro Jaya dan jajarannya berhasil mengamankan 667 tersangka kasus narkoba. Sekitar 18-9 persen dari 667 tersangka, terdapat sekitar 113 tersangka adalah generasi muda belia yang berada di kisaran usia anak SD. Dua hal yang disampaikan di atas merupakan masalah yang baru sedikit diungkap dari sejumlah banyak permasalahan yang terjadi di dunia pendidikan, khususnya terkait dengan karakter siswa.

Di 2014, menurut Data Direktorat Jenderal Pengelolaan Utang Kementerian Keuangan Republik Indonesia yang dikutip DetikFinance, menyebutkan bahwa hingga akhir September 2013 utang pemerintah Indonesia telah mencapai Rp 2.273 triliun (Senin, 28/10/2013). Jumlah utang pemerintah Indonesia tersebut, jika dibagi rata dengan jumlah penduduk Indonesia hasil Sensus Penduduk tahun 2010 sebanyak 237.641.326 jiwa, maka setiap orang Indonesia pada akhir September 2013 telah memiliki utang sebesar Rp 9.564 juta.

Hal ini menunjukkan bahwa Indonesia belum menjadi negara yang mandiri yang pada akhirnya menurun kepada masyarakatnya, menjadi masyarakat yang kurang memiliki jiwa kewirausahaan. Jika kedua kondisi ini dibiarkan maka akan menimbulkan kondisi yang saling "mengunci", artinya jika moral dan karakter bangsa menurun maka daya juang jiwa kewirausahaan akan merosot dan jika jiwa kewirausahaannya rendah maka pendapatan dari masyarakat juga rendah sehingga pada gilirannya akan memicu tingkat kejahatan di lingkungan masyarakat sebagai puncak dari pudarnya moral dan karakter bangsa.

Dengan kondisi yang mengkhawatirkan di atas, pemerintah mencari jalan untuk melakukan upaya pembinaan melalui pendidikan. Oleh karena itu, lahirlah program pilot project untuk mengintegrasikan pendidikan karakter dan kewirausahaan dalam Kurikulum Tingkat Satuan Pendidikan (KTSP) di sejumlah sekolah di tanah air. Kementerian Pendidikan Nasional mencanangkan penerapan pendidikan karakter mulai tahun 2010.

Di 2012, muncul gagasan untuk mengembangkan lebih lanjut pendidikan karakter dan kewirausahaan yang tidak hanya bersifat suplemen tetapi sudah menjadi warna dari sebuah kurikulum. Pada kesempatan yang tepat, lahirlah Kurikulum 2013 yang mengakumulasi setiap harapan pendidikan karakter. Nilai-nilai pendidikan karakter (dan juga kewirausahaan) terintegrasi pada setiap mata pelajaran yang dirumuskan dalam Kompetensi Inti aspek sikap spiritual (KI-1) dan aspek sikap sosial (KI-2). Nilainilai pendidikan karakter dan kewirausahaan tidak diajarkan secara langsung, namun dikembangkan secara nurturant effect setelah kompetensi dasar dari Kompetensi Inti Pengetahuan (KI-3) dan Kompetensi Inti Keterampilan (KI-4) disampaikan (Ahmad Yani, 2014; 69).

Beberapa penelitian yang telah dilakukan terkait model pendidikan karakter, maupun model pendidikan kewirausahaan, pendidikan karakter dengan pendekatan komprehensif yang diintegrasikan terbukti efektif untuk meningkatkan pengamalan nilainilai target yang ingin dicapai, sekaligus juga meningkatkan hasil belajar Bahasa Indonesia, IPA, dan IPS (Zuchdi, dkk, 2010:11).

Sumardiningsih, dkk (tanpa tahun) menyimpulkan tentang hasil penelitiannya berkaitan dengan pengembangan model pengintegrasian pendidikan karakter dan kewirausahaan di SMK di Yogyakarta, menunjukkan, bahwa setelah diimplementasikan karakter, sikap, minat dan perilaku wirausaha siswa mampu meningkatkan sikap dan minat terhadap wirausaha. Model pengintegrasian pendidikan karakter dan kewirausahaan diwujudkan dalam perangkat pengintegrasian berupa silabus dan RPP yang didalamnya memuat nilai-nilai karakter dan kewirausahaan.

Wagiran (2011) menguatkan dengan hasil penelitiannya tentang implementasi kearifan lokal dalam proses pembelajaran dapat "diterapkan terintegrasi pada mata pelajaran, dapat pula menjadi mata pelajaran khusus atau diimplementasikan dalam budaya/iklim sekolah, kepemimpinan, dan manajemen sekolah, maupun hubungan sinergis dengan masyarakat."

Dalam konteks pendidikan pesantren, Widodo \& Nugraha (2014: 178) menjelaskan hasil penelitiannya bahwa,

"masih rendahnya jiwa kewirausahaan santri di pesantren". Untuk menumbuhkan perilaku kewirausahaan para santri yang tinggal di pondok pesantren perlu disusun model pendidikan kewirausahaan berba- 
sis karakteristik jiwa kewirausahaan santri.

Pendidikan kewirausahaan telah lama diimplementasikan di sekolah, baik secara khusus pada mata pelajaran kewirausahaan, juga terintegrasi pada mata pelajaran lain. Untuk menanamkan nilai-nilai kewirausahaan pada diri siswa perlu dilakukan dengan berbagai cara, tidak hanya dilakukan secara formal di sekolah, juga di lingkungan masyarakat. (Susilowati, Susantiningrum: 2013) menyimpulkan bahwa siswa SMA memiliki nilai-nilai pokok kewirausahaan setelah dilakukan pengintegrasian nilai-nilai tersebut pada semua mata pelajaran di SMA.

Perilaku wirausaha dibentuk oleh tiga faktor, yaitu bawaan sejak lahir, lingkungan, dan latihan (Wahyudin, 2012 :61), selanjutnya dari ketiga faktor tersebut, faktor latihan akan memberikan pengaruh yang lebih baik dibandingkan kedua faktor lainnya. Melalui pelatihan-pelatihan yang dilakukan perilaku wirausaha dapat terbentuk khususnya terkait dengan kemandirian psikologis dan sikap mental wirausaha. Hasil penelitian menunjukkan bahwa melalui penerapan model pelatihan kewirausahaan berlatar ekokultural secara efektif dapat meningkatkan keberdayaan masyarakat miskin di pedesaan (Wahyudin, 2012: 63).

Dalam perkembangan berikutnya, kita memahami bahwa kurikulum tidak berhenti hanya pada tataran konsep, gagasan, atau desain kurikulum, namun akan terus dikawal keberhasilannya dalam proses implemantasi kurikulum. Hasan (1988) menegaskan bahwa kurikulum memiliki 4 (empat) dimensi, dimana setiap dimensi saling berhubungan, keempat dimensi kurikulum tersebut meliputi: (1) kurikulum sebagai suatu ide/gagasan, (2) kurikulum sebagai sebuah rencana, (3) kurikulum sebagai proses, dan (4) kurikulum sebagai hasil. Dari hasil pengamatan, internalisasi nilai-nilai tersebut tidak dapat terlepas dari konteks budaya. Latar belakang budaya setempat di sekitar sekolah memiliki peranan penting dalam "interpretasi" terhadap nilai-nilai yang dikembangkan. Dengan demikian, untuk mengembangkan pendidikan karakter sebaiknya berbasis pada budaya setempat (etnopedagogis). Tujuannya adalah untuk membentuk perilaku yang disesuaikan dengan budaya setempat agar siswa dapat mudah berinteraksi, beradaptasi dengan lingkungan sekitarnya, dengan tidak melupakan nilai-nilai universal masih tetap digunakan.

Selain latar belakang di atas, Dhikrul
Hakim (2012) mengatakan bahwa, pengembangan pendidikan kewirausahaan
berdasarkan nilai-nilai budaya dan karakter
bangsa, sangat strategis bagi keberlangsun-
gan dan keunggulan bangsa di masa men-
datang. Pengembangan itu harus dilakukan
melalui perencanaan yang baik, pendekatan
yang sesuai,dan metode belajar serta pem-
belajaran yang efektif. Sesuai dengan sifat
suatu nilai, pendidikan budaya dan karak-
ter bangsa adalah usaha bersama sekolah;
oleh karenanya harus dilakukan secara ber-
sama oleh semua guru dan pemimpin se-
kolah, melalui semua mata pelajaran, dan
menjadi bagian yang takterpisahkan dari
budaya sekolah. Dengan demikian, mod-
el pendidikan karakter dan kewirausahaan
berbasis etnopedagogis semakin penting.

Keragaman budaya dan bahasa di Indonesia merupakan potensi yang tidak boleh diabaikan dalam proses pendidikan. Salah satunya agar jangan sampai siswa tidak mengambil pelajaran dari kearifan lokal dari budayanya sendiri. Menumbuhkan nilainilai karakter dan kewirausahaan berbasis kearifan lokal perlu dikembangkan sedini mungkin, agar kearifan tersebut tertanam dalam jiwa siswa. Dengan demikian siswa sebagai generasi penerus diharapkan dapat menjaga, melestarikan, dan meningkatkan potensi-potensi daerah yang ada dalam melaksanakan kehidupan bermasyaraka juga dalam membangun negerinya.

Artikel ini akan mengusulkan model pendidikan karakter dan kewirausahaan berbasis etnopedagogis di sekolah dasar, sebuah konsep tentang pengintegrasian dan harmonisasi pengembangan nilai karakter dan kewirausahaan di sekolah dengan nilai budaya masyarakat setempat.

Ada dua langkah pokok penelitian yang dilakukan dalam penelitian ini, yaitu mengidentifikasi nilai-nilai kearifan lokal (etnopedagogis) di masyarakat kampung adat, kemudian langkah kedua yaitu pengintegrasian di dalam penerapan proses pendidikan melalui memasukan nilai-nilai karakter dan kewirausahaan dalam kurikulum tingkat satuan pendidikan di sekolah dasar. Proses identifikasi nilai-nilai kearifan lokal (etnopedagogis) dilaksanakan di Kampung adat Cikondang, Kabupaten Bandung.

Pada tahap identifikasi, peneliti menyediakan sejumlah pertanyaan dan alat obersevasi. Tujuan utamanya adalah "mendaftar" nilai-nilai yang mengandung pendidikan kearifan lokal. Dari hasil identifikasi, selanjutnya dilakukan proses interpretasi terhadap setiap nilai yang diperkirakan mengandung nilai-nilai 
pendidikan karakter dan kewirausahan. Hasil interpretasi kemudian dikemas dalam bentuk perangkat pembelajaran. Di akhir kegiatan diharapkan melahirkan Model Pendidikan Karakter Bangsa dan Kewirausahan yang berbasis etnopedagogis.

Dengan langkah di atas, penelitian ini memiliki keunggulan yaitu dapat menjaga keharmonisan nilai budaya setempat dengan nilai pendidikan karakter yang diajarkan di sekolah-sekolah. Usaha memadukan nilainilai yang berlaku di masyarakat adat dengan nilai yang diajarkan di sekokah-sekolah akan menjadi bahan pertimbangan para guru. Guru yang biasanya hanya mengajarkan materi dari apa yang terdapat di dalam buku perlu memasukkan nilai-nilai budaya, yang berakar dari kearifan masyarakat setempat. Sebaliknya bagi masyarakat setempat akan memiliki perluasan media sosialisasi nilai budaya karena pihak sekolah dapat menanamkan nilai budaya setempat secara harmonis dengan pelajaran di sekolah.

Hasil penelitian ini dapat dimanfaatkan untuk menciptakan sekolah sebagai pusat pembudayaan dan pendidikan karakter dan kewirausahaan peserta didik secara lebih berbudaya. Artinya, jika di lingkungan masyarakat terdapat budaya dan karakter yang sesuai dengan cita-cita bangsa Indonesia yang maju dan harmonis, maka hasil penelitian ini akan memperkaya budaya masyarakat. Sekolah dapat dijadikan sebagai agent of change dalam memperbaiki budaya dan karakter bangsa. Selain itu, sekolah dapat dijadikan arena internalisasi pendidikan kewirausahaan.

\section{Pendidikan Karakter dan Kewirau- sahaan}

Proses pendidikan bukan hanya mengajar untuk menjadikan orang pintar dan pandai berpengetahuan, akan tetapi juga menuntun tumbuhnya budi pekerti dalam kehidupan agar kelak menjadi manusia berpribadi yang beradab dan bersusila. Pembinaan moral dan karakter bangsa sangat terkait erat dengan peningkatan kualitas pembangunan pendidikan dan peningkatan kesejahteraan masyarakat. Dalam kaitan dengan penyelenggaraan pendidikan, pemerintah telah bertekad untuk menjadikan pendidikan menjadi landasan utama dalam pembinaan dan penumbuhkembangan karakter positif bangsa.

Masyarakat Indonesia telah mengalami krisis penemuan jati diri, karenanya sudah sepatutnya menemukan lagi jati diri melalui pemaknaan kembali dan rekonstruksi nilainilai luhur budaya melalui nilai-nilai kearifan lokal yang perlu dipelajari secara substantif. Untuk mengimplementasikan nilai-nilai kearifan lokal melalui proses pembelajaran dengan membangun pendidikan karakter di sekolah memerlukan revitalisasi budaya lokal yang relevan untuk membangun pendidikan karakter (Susanti, 2011).

Pendidikan karakter berbasis kearifan lokal dapat mengantarkan peserta didik untuk dapat mencintai nilai-nilai daerahnya sendiri. Kecintaan siswa pada daerahnya dapat mewujudkan ketahanan daerah. Menurut Susanti (2011),

"Ketahanan daerah adalah kemampuan suatu daerah yang ditunjukkan oleh kemampuan warganya untuk menata diri sesuai dengan konsep yang diyakini kebenarannya dengan jiwa yang tangguh, semangat yang tinggi, serta dengan cara memanfaatkan alam secara bijaksana,"

Anak-anak diperkenalkan dengan lingkungan terdekatnya, melalui cara tersebut siswa dapat mencintai daerahnya sepenuh hati. Nilai-nilai disiplin dan kerja keras diajarkan pada siswa dalam proses pembelajaran tanpa ada kesenjangan dengan nilai yang berlaku di lingkungan budayanya sendiri. Inilah yang dimaksud dengan pendidikan yang berbasis etnopedagogis yang sarat dengan kandungan nilai kearifan lokal.

Kearifan lokal dapat didefinisikan sebagai kebijaksanaan atau nilai-nilai luhur yang terkandung dalam kekayaan-kekayaan budaya lokal berupa tradisi, petatah-petitih dan semboyan hidup (Pikiran Rakyat, 4 Oktober 2004 dalam Susanti, 2011). Lebih lanjut Naritoom (Wagiran, 2009) merumuskan Local wisdom dengan definisi

"the knowledge that discovered or acquired by lokal people through the accumulation of experiences in trials and integrated with the understanding of surrounding nature and culture. Local wisdom is dynamic by function of created local wisdom and connected to the global situation."

Kearifan lokal adalah bagian dari nilainilai budaya. Setiap budaya suatu memiliki suatu pandangan hidup, berbagai hal tentang hidup manusia, akan memancarkan ratusan bahkan ribuan kearifan lokal. Susanti (2011) menegaskan bahwa kearifan lokal dapat dipahami sebagai gagasan-gagasan, nilainilai, pandangan-pandangan setempat yang bersifat bijaksana, penuh kearifan, dan bernilai baik yang tertanam dan dapat diterapkan oleh suatu kumpulan anggota 
masyarakatnya.

Pembentukan karakter tidak dapat dilakukan secara instan, diperlukan waktu dalam pelaksanaannya untuk melihat perubahan pada diri peserta didik yang memiliki karakter kuat serta jiwa kewirausahaan yang baik. Zainudin, dkk (2014: 16) melakukan 2 (dua) siklus dalam melaksanakan penelitiannya untuk melihat perubahan karakter peduli, yaitu "dapat terlihat pada perubahan aspek afektif siswa, khususnya dalam bentuk kerjasama tanpa membeda-bedakan, baik kualitas maupun kuantitas antar temannya."

Untuk menumbuhkan nilai-nilai kearifan lokal di daerah dimana siswa tinggal, perlu adanya intervensi dalam proses pendidikan utuk memberikan pemahaman dan pembiasaan kepada siswa tentang nilainilai moral yang sesuai dengan kearifan lokal setempat. Kegiatan tersebut saat ini dikenal dengan pendidikan karakter.

Gaffar dalam Syarbini (2012: 17) menjelaskan bahwa pendidikan karakter adalah

"sebuah proses transfomasi nilai-nilai kehidupan untuk ditumbuhkembangkan dalam kepribadian seseorang, sehingga menjadi satu dalam perilaku orang tersebut". Tujuannya adalah untuk menanamkan nilai-nilai baik kepada peserta didik agar memiliki karakter yang baik (good character) sesuai dengan nilai-nilai yang dirujuk, baik nilai-nilai agama, budaya maupun falsafah bangsa.

Penanaman nilai-nilai karakter yang sesuai dengan kearifan lokal akan lebih efektif jika diterapkan melebur dalam sebuah proses pendidikan, khususnya proses pembelajaran. Melalui proses penanaman nilai yang dilakukan secara alamiah dan natural, hasilnya akan lebih baik, jika dibuat dengan mata pelajaran khusus. Hal yang paling penting dalam penanaman nilai-nilai karakter ini adalah dilihat dari sisi proses, bukan isinya. Karena melalui proses, penanaman nilai-nilai karakter dapat berlangsung dimanapun, sehingga peserta didik dapat lebih memaknainya atas tindakan-tindakan yang dilakukannya (Koesoema: 2012).

Kewirausahaan merupakan paduan dari semangat, nilai-nilai, prinsip, sikap, kiat, seni dan tindakan nyata dalam mengembangan usaha. Adapun substansi kewirausahaan adalah kreativitas dan inovasi yang menjadi produk pendidikan, pengalaman, nilai pribadi, visi dan komitmen. Munculnya kewirausahaan berangkat dari adanya keinginan untuk menolong diri sendiri di saat menghadapi tantangan sehingga memunculkan motivasi yang menggerakkan pencarian alternatif, gagasan, ide dan rencana, hingga akhirnya dipilih suatu alternatif tindakan yang memiliki nilai unggul dibanding pilihan lainnya (Wahyudin, 2012:59).

Mengutip Kuncoro, Wahyudin (2012) menyebutkan sejumlah karakter kewirausahaan berupa: komitmen dan kesungguhan, tanggung jawab, ambisi, tangguh menghadapi risiko, percaya diri dan optimistik, berdaya cipta dan dinamis, kebutuhan feedback, energik, melebihi nilai rata-rata, bertumbuh dan berkembang, mengambil pelajaran dari kegagalan, kepemimpinan .

Pendidikan kewirausahaan merupakan upaya sistemik untuk menumbuhkan karakter wirausaha pada seseorang atau sekelompok orang. Dalam penelitian Slamet Widodo (2014: 175) karakter tersebut meliputi hasrat berprestasi, etos kerja, semangat dan inovatif.

Pada kewirausahaan, hasrat berprestasi ditunjukkan oleh tindakan untuk melakukan sesuatu dengan lebih baik dan lebih efisien. Disebutkan bahwa diantara cirinya adalah adanya keinginan mengatasi sendiri permasalahan pribadi, menginginkan masukan balik untuk menilai keberhasilan dan kegagalan, memiliki tanggung jawab yang besar, kesiapan memperhitungkan risiko, memandang tantangan dengan secara positif (Widodo, 2014: 176). Adapun etos kerja berkaitan dengan kemauan untuk melakukan sesuatu dengan sungguh-sungguh, bekerja dengan keras demi mencapai tujuan.

Sebagaimana kaitannya dengan semangat, hal ini ditunjukkan oleh adanya kemampuan menghadapi kegagalan, siap dan berani, mempunyai ketangguhan menanggung risiko dan pantang menyerah. Sedangkan inovasi merupakan kemampuan memunculkan hal-hal baru baik dalam produk barang atau jasa, sehingga dapat bertahan dalam tingkat persaingan yang tinggi.

Pendidikan kewirausahaan dapat dilaksanakan secara terpadu dalam proses pendidikan di sekolah dengan berbagai kegiatannya. Beberapa model pengintegrasian pendidikan kewirausahaan di sekolah dapat berbentuk: (a) pendidikan kewirausahaan termuat di dalam seluruh mata pelajaran, (b) pendidikann kewirausahaan termuat dalam kegiatan ekstra kurikuler, (c) pendidikan kewirausahaan dalam pengembangan 
diri, (d) pendidikan kewirausahaan yang mempraktikkan teori, (e) pendidikan kewirausahaan dalam buku dan bahan ajar, (f) pendidikan kewirausahaan melalui pembentukan budaya sekolah, dan ( $\mathrm{g}$ ) memasukkan pendidikan kewirausahaan ke dalam muatan lokal sekolah.

Melalui pengembangan model pendidikan karakter dan kewirausahaan berbasis etnopedagogis di sekolah memiliki relevansi yang kuat dalam mengembangkan kecakapan hidup siswa dengan berpijak pada pemberdayaan keterampilan serta potensi daerah yang dimiliki. Dalam setiap keragaman bangsa, budaya dan bahasa di Indonesia terdapat nilai-nilai budaya luhur dan keunggulan lokal atau kearifan lokal tersendiri yang dapat dijadikan sarana untuk mengembangkan kepribadian dan potensi siswa sebagai bekal mereka di masa yang akan datang. Hal tersebut dapat dijadikan dasar pengembangan model pembelajaran pendidikan karakter yang berbasis etnopedagogis atau kearifan lokal.

Untuk mengimplementasikan model tersebut tentunya diperlukan dukungan dan kemampuan guru. Guru dapat menyisipkan nilai-nilai budaya yang dibawa dari lingkungan keluarga dan masyarakat untuk disampaikan kepada siswanya agar dapat dimengerti, dimaknai, dan diterapkan dan menjadi identitas diri siswa sebagai anggota masyarakat yang berbudaya. Proses tersebut akan berhasil apabila guru memiliki wawasan kearifan lokal yang cukup baik, sehingga dapat menggunakannya dalam pelaksanaan proses pendidikan karakter.

\section{Model Pendidikan Karakter dan Ki- wausahaan Berbasis Etnopedagogis}

Model pendidikan karakter dan kewirausahaan berbasis etnopedagogis adalah model pendidikan yang harus menunjukkan keteladanan yang mencerminkan nilainilai karakter yang ingin dikembangkan. Pendidikan karakter memercayai adanya keberadaan moral absolute, yaitu pemahaman mengenai mana yang baik dan benar. Pendidikan karakter menanamkan kebiasaan (habituation) tentang hal yang baik sehingga peserta didik menjadi paham tentang mana yang baik dan salah (domain kognitif), mampu merasakan nilai yang baik (domain afektif) dan sebagai domain perilakunya adalah biasa melaksanakan nilai kebaikan (Kemdiknas, 2011: 10).

Model pendidikan karaker dan kewirausahaan berbasis etnpedagogis yang dikembangkan ini didasarkan pada nilainilai karakter yang ada pada kampung adat dimana sekolah berada dimaksudkan agar pengintegrasiannya menjadi lebih kuat. Pengintegrasian ini berdampak pada siswa agar lebih mengenal budayanya, juga agar siswa memiliki "sense of belonging" yang tinggi, sehingga mereka dapat menjadi duta pelestarian alam dan lingkungan di sekitarnya bahkan sampai ke lingkungan yang lebih luas.

Langkah penerapan pendidikan karakter
dan kewirausahaan berbasis etnopeda-
gogis di SD diperlukan strategi yang te-
pat dengan memperhatikan rambu-rambu
pokok pengintegrasian pendidikan karakter
dan kewirausahaan yang dikeluarkan oleh
Puskurbuk Kemdikbud (2010: 56-65).

Berdasarkan bagan di atas, langkah pertama yang harus dikembangkan sekolah dalam mengembangkan model pendidikan karakter dan kewirausahaan berbasis etnopedagogis di Sekolah Dasar adalah melakukan identifikasi puncak-puncak kearifan lokal sebagaimana dicontohkan dalam penelitian ini. Dari hasil identifikasi, nilai-nilai karakter dan kewirausahaan yang baik diturunkan dalam sejumlah indikator pembelajaran.Setelah itu selajutnya dibuat bahan bacaan dan atau suplemen bahan ajar, diintegrasikan dalam setiap mata pelajaran. Mengembangkan bahan bacaan yang akan dijaungkau oleh peserta didik di perpustakaan. Bahan bacaan berupa buku pengayaan atau bentuk lainnya yang mengangkat budaya masyarakat adat di daerah setempat. Buku tersebut dirancang agar mengangkat nilainilai pendidikan karakter dan kewirausahaan.

Untuk sekolah yang melaksanakan Kurikulum 2013, dapat mengadaptasi nilai dari Kompetensi Inti aspek sosial (KI-2). Prosesnya dilaksanakan mulai dari memasukkan materi dalam Rencana Pelaksanaan Pembelajaran (RPP), pada saat pelaksanaan di kelas, dan mengajukan pertanyaan dalam butir soal saat evaluasi pembelajaran. Pada tahap perencanaan ini RPP dirancang agar muatan maupun kegiatan pembelajarannya memfasilitasi untuk mengintegrasikan nilainilai kewirausahaan.

Langkah-langkah pembelajaran dengan nilai-nilai kewirausahaan yang diangkat dari kearifan lokal. Nilai-nilai kewirausahaan sama dengan apa yang ditetapkan oleh pemerintah seperti kemandirian, kreatif, berani mengambil resiko,berorientasi pada tindakan, kepemimpinan, dan kerja keras. Hal yang berbeda adalah kemasannya. Jika 
kemasannya berupa cerita, maka tokoh ceritanya berasal dari kearifan lokal.

Pendidikan karakter dan kewirausahaan dipadukan pula dalam kegiatan ekstrakurikuler. Kegiatan ekstrakurikuler adalah kegiatan pendidikan di luar mata pelajaran untuk membantu pengembangan peserta didik sesuai dengan kebutuhan, potensi, bakat, dan minat mereka melalui kegiatan yang secara khusus. Kegiatan ektrakurikuler yang relevan dengan pengembangan budaya lokal misalnya olah raga bela diri dan kesenian. Setiap kampung adat biasanya memiliki tradisi olah raga bela diri, di Sunda dikenal dengan pencak silat. Melalui pelatihan pencak silat, peserta didik langsung dididik jiwa kewirausahaan. Kesenian yang dikembangkan juga bukan dari luar, tetapi kesenian yang dikembangkan di kampung adat setempat.

Pendidikan kewirausahaan melalui pengembangan diri. Kegiatan pengembangan diri merupakan upaya pembentukan karakter termasuk karakter wirausaha dan kepribadian peserta didik yang dilakukan melalui kegiatan pelayanan bimbingan konseling. Untuk satuan pendidikan khusus, pelayanan konseling menekankan peningkatan kecakapan hidup sesuai dengan kebutuhan khusus peserta didik yang relevan dengan kearifan lokal.

Dalam program pengembangan diri, perencanaan dan pelaksanaan pendidikan kewirausahaan dapat dilakukan melalui pengintegrasian kedalam kegiatan seharihari sekolah, misalnya kegiatan 'business day' (bazar, karya peserta didik). Dalam program pengembangan diri, perencanaan dan pelaksanaan pendidikan kewirausahaan dilakukan melalui pengintegrasian kedalam kegiatan sehari-hari sekolah melalui kegiatan rutin sekolah, kegiatan spontan, keteladanan, dan pengondisian. Sekolah menciptakan suacana kehidupan sekolah yang mencerminkan nilai-nilai kewirausahaan bangsa yang diinginkan.

Pelaksanaan pembelajaran yang aktif dalam mengembangkan pendidikan karakter dan kewirausahaan. Pembelajaran dirancang agar ketiga ranah pembelajaran yaitu kognitif, afektif, dan psikomotor mengandung nilai kewirausahaan. Jika dikaitkan dengan pemberlakuan Kurikulum 2013, nilai-nilai karakter dan kewirausahaan dapat diintegrasikan dalam Kompetensi Inti sikap sosial (KI-2) dan Kompetensi Inti Keterampilan (KI- 4). Pengintegrasian pendidikan karakter dan kewirausahaan melalui muatan lokal. Di setiap sekolah diberi peluang untuk mengembangkan kurikulum muatan lokal. Mata pelajaran muatan lokal dapat dirancang agar memasukkan budaya lokal, keterampilan, nilai-nilai luhur budaya setempat dan mengangkat permasalahan sosial dan lingkungan yang pada akhirnya mampu membekali peserta didik dengan keterampilan dasar (life skill) sebagai bekal dalam kehidupan sehingga dapat menciptakan lapangan pekerjaan.

\section{Identifikasi Nilai Karakter dan Ke- wirausahaan Masyarakat Kampung Adat Cikondang}

Secara administratif, Kampung Cikondang berada di Desa Lamajang, Kecamatan Pangalengan, Kabupaten Bandung. Nama Cikondang berasal dari pohon Kondang dekat mata air (seke), sehingga disebut $\mathrm{Ci}$ dan Kondang. Ci artinya cai = air dan Kondang artinya pohon Kondang. Luas lahan Kampung Cikondang hanya sekitar tiga hektar dengan bangunan rumah adat yang disebut Bumi Adat.

Mata pencaharian utama mayoritas penduduk Kampung Cikondang adalah petani. Peralatan produktif yang digunakan adalah alat-alat pertanian, yaitu cangkul, parang, bajak sawah dengan kerbau, gasrok untuk menyiang, sabit, pupuk kimia serta lumbung padi. Lumbung padi merupakan tempat ditaruhnya semua hasil dari pertanian yang telah dihasilkan untuk menjauhkan dari hama pemakan beras seperti tikus dan yang lainnya. Sebelum disimpan di dalam lumbung padi, padi ditumbuk lisung untuk mendapatkan padi yang banyak. Selain dari pertanian, mata pencaharian lain yang ditekuni oleh masyarakat cikondang yaitu berdagang. Alat-alat yang digunakan dalam berdagang yaitu bahan yang akan didagangkan serta alat untuk mengolah bahan makanan apabila terdapat makanan yang akan dijual.

Komunitas masyarakat Adat Kampung Cikondang jumlahnya relatif sedikit, yaitu hanya sekitar 389 jiwa saja dengan demikian sistem kemasyarakatannya tidak terlalu rumit. Tokoh adat yang dihormati adalah kuncen. Fungsi kuncen adalah untuk menjaga tradisi adat. Mereka menyebutkan kuncen sebagai pemelihara dan penjaga Bumi Adat. Berdasarakan sejarah di Kampung Cikondang telah ada tujuh kuncen yaitu (1) Ma Empuh, (2) Ma Akung, (3) Ua Idil (Anom Idil), (4) Anom Rumya, (5) Aki Emen (Kuncen Sementara), (6) Anom Samsa, dan (7) Anom Djuhana (Kuncen Sementara). Untuk 
menempati jabatan kuncen harus memiliki beberapa syarat yaitu harus memiliki ikatan darah atau masih keturunan leluhur Bumi Adat. Calon Kuncen harus laki-laki, dipilih berdasarkan wangsit dan musyawarah para tetua adat. Anak kuncen tidak dapat diangkat langsung jadi kuncen tergantung pada ketentuan ikatan darah.

Pengetahuan masyarakat Cikondang sangat sarat dengan falsafah hidup tritangtu, yaitu keseimbangan hubungan antara Allah, alam, serta manusia. Alam merupakan sahabat manusia, sehingga apabila kita berbuat baik terhadap alam maka alam akan memberikan semua hal yang terbaik yang dipunyai untuk manusia. Hubungan antara manusia yang baik dengan sang Pencipta dan alam akan menemukan kebahagiaan.

Upacara adat yang dilakukan oleh masyarakat kampung adat cikondang banyak dilakukan di dalam berbagai kegiatan. Seperti di dalam kegiatan ekonomi, musibah, bangun rumah, tempat usaha, kelahiran, perkawinan, kematian dilakukan dengan adanya syukuran yang didampingi dengan adanya kemenyan serta kembang yang digunakan untuk melengkapi upacara adat yang akan dilakukan. Untuk kegiatan ekonomi, musibah, bangun rumah, tempat usaha bisa dilakukan kapan saja sesuai dengan kebutuhan.

Nilai kearifan lokal terkait dengan pendidikan karakter dan kewirausahaan dapat diamati dari upacara kelahiran. Di Cikondang, ada beberapa tahapan dalam proses kelahiran, yaitu upacara satu bulan, empat bulan, tujuh bulan, dan kelahiran. Ketika janin pada umur satu bulan, terdapat upacara pangasih dengan cara ibu yang sedang hamil mendatangi dukun bayi untuk diminta beberapa buah panglai untuk menjaga kehamilan dari hal-hal yang tidak diinginkan. Harapan yang muncul dari upacara satu bulanan ini adalah bayi jangan sampai hilang dari kandungan. Pada upacara satu bulanan, diadakannya pengajian yang dikhususkan dengan membaca Surat Maryam, Yaasin, dan Yusuf dengan harapan memunyai anak yang cantik seperti Siti Maryam dan tampan seperti Nabi Yusuf.

Prosesi seputar acara perkawinan juga mengandung makna pendidikan karakter dan kewirausahaan. Upacara perkawinan diawali dari acara melamar atau bertunangan atau khitbah. Khitbah merupakan kata lain dari tunangan, pihak laki-laki mendatangi kepada pihak perempuan untuk menanyakan kelanjutan dari sebuah hubungan, dengan maksud menjalankan tradisi dari turun temurun. Pada acara khitbah dibutuhkan sepasang cincin apabila pasangan yang akan menikah mampu untuk menyediakan dengan maksud pasangan tidak akan terpisahkan dan akan menjadi kunci dalam sebuah perkawinan. Harapan yang muncul pada acara khitbah yaitu menjadikan pasangan meneruskan ke acara akad.

\section{Implementasi Model Pembelajaran Karakter dan Kewirausahaan Berba- sis Etnopedagogis}

Setelah melakukan identifikasi nilainilai karakter dan kewirausahaan kemudian dikembangkan perangkat pembelajaran yang disesuaikan dengan nilai-nilai karakter budaya kampung cikondang, juga menyesuaikan dengan kurikulum yang diberlakukan saat itu yaitu kurikulum 2013. Ujicoba dilakukan di SD Lamajang 1 yang terdapat di Kampung Cikondang Kabupaten Bandung. Penerapan model pembelajaran ini dilaksanakan dengan pendekatan tematik dan saintifik dengan mengambil sub tema "Jenis-jenis Pekerjaan". Dilaksanakan selama 1 (satu) bulan. Secara umum penerapan model ini efektif dan cukup baik diterapkan di sekolah.

Pertemuan pertama siswa diberikan tayangan video untuk melihat berbagai pekerjaan yang ada di lingkungan pedesaan, kemudian siswa mengerjakan Lembar Kerja Siswa (LKS), setelah selesai mengerjakan kemudian siswa mempresentasikan di depan kelas. Sebagai penguatan guru memberikan penjelasan tentang jenis pekerjaan kemudian memberikan penekanan tentang nilai-nilai kemandirian dan kerja keras dalam bekerja. Setiap siswa merasa senang diberi tugas untuk melakukan wawancara sejumlah orang yang memiliki jenis pekerjaan yang beragam. Antusiasme siswa selama proses pembelajaran juga memberikan gambaran bahwa proses pembelajaran ini cukup menyenangkan dan mampu meningkatkan keaktifan siswa dalam belajar. Guru juga menjelaskan tentang nilai kreatif, kemandirian, kerja keras, berani ambil resiko dikaitkan dengan jenis pekerjaan di setiap wilayah yang berbeda karakteristiknya.

Pertemuan kedua siswa diajak untuk mewawancarai berbagai jenis pekerjaan yang berbeda yang ada di kampung adat. Misalnya petani, pedagang, peternak, pengrajin, (LKS disiapkan dengan menggunakan pendekatan nilai-nilai karakter dan kewirausahaan). Siswa secara berkelompok membuat laporan tertulis di rumah untuk dilaporkan hasilnya di hari berikutnya. Guru memberikan penguatan tentang jenis-jenis pekerjaan yang ada di kampung adat dan mengaitkannya dengan nilai-nilai karakter dan kewirausahaan.

Pertemuan ketiga siswa secara 
berkelompok tampil ke depan untuk menyampaikan hasil wawancara dengan seorang pekerja yang sudah ditemuinya di lingkungan adat. Guru menguatkan pembelajaran dengan memberikan penguatan konsep bahwa di kampung adat terdapat jenis-jenis pekerjaan yang mendukung terhadap kelestarian kampung adat. Guru menjelaskan tentang nilai-nilai karakter dan kewirausahaan yang ada di kampung adat yang dapat diterapkan oleh siswa baik dalam belajar maupun dalam kehidupan di keluarga dan masyarakat.

Selain peningkatan antusiasme siswa dalam belajar terlihat lebih baik. Hal lain dapat terlihat juga pada perolehan hasil belajar, yaitu dengan melihat hasil pre dan post test. Untuk lebih jelas dapat dilihat pada Tabel 1 berikut ini:

\section{Tabel 1}

\section{Nilai Rata-rata}

\begin{tabular}{|c|c|c|c|c|c|}
\hline & Test & $\mathrm{N}$ & Mean & Std. & Std. \\
\hline \multirow{2}{*}{ Nilai } & Posttest & 18 & 6.5167 & .48172 & .11354 \\
\cline { 2 - 6 } & Pretest & 18 & 5.4111 & .98869 & .23304 \\
\hline
\end{tabular}

Berdasarkan data diatas dapat dijelaskan bahwa rata-rata nilai posttest lebih tinggi dibandingkan nilai pre test. Kemudian dilakukan analisis dengan menggunakan independent Sample Test. Berdasarkan hasil perhitungan diperoleh nilai $\mathrm{T}_{\text {hitung }}=$ 4,265, sedangkan $T_{\text {tabel }}=1,69(\mathrm{df}=34)$. Uji signifikansi ditolak Ho menjelaskan bahwa jika nilai $\mathrm{T}_{\text {hitung }}>\mathrm{T}_{\text {tabel }} ; \mathrm{H}_{1}$ diterima, yaitu $4,26>1,69$. Dengan demikian simpulannya adalah bahwa hipotesis kerja diterima $\left(H_{1}\right.$ diterima)

Fakta-fakta di atas menunjukkan bahwa sumber nilai karakter dan kewirausahaan dapat ditemukan di lingkungan sekitar kita. Melalui penerapan kurikulum 2013, nilai karakter yang dijadikan rujukan adalah nilai-nilai yang bersifat universal seperti nilai religius, jujur, toleran, disiplin, kerja keras, dan lain-lain. Demikian juga, nilai kewirausahaan juga dipilih adalah nilai yang bersifat umum seperti mandiri, kreatif, berani mengambil resiko, berorientasi pada tindakan, kepemimpinan, dan lain-lain. Nilai-nilai yang telah disebutkan di atas, pada Kurikulum 2013 dirumuskan dalam kolom Kompetensi Inti aspek spiritual dan sosial dengan memilih beberapa nilai yang penting yaitu jujur, disiplin, tanggung jawab, peduli (gotong royong, kerjasama, toleran, damai), santun, responsif dan pro-aktif dan menunjukkan sikap sebagai bagian dari solusi atas berbagai permasalahan bangsa.

Hasil penelitian menunjukkan bahwa di lingkungan Kampung Adat di Jawa Barat memiliki "simpanan" kearifan lokal tentang pendidikan karakter dan kewirausahaan. Jika ukurannya adalah kekayaan ekonomi, memang tidak akan terlihat secara langsung karena adat mereka melarang untuk menumpuk kekayaan. Bentuk rumah hanya diperbolehkan dengan berbahan bambu dan kayu sehingga tidak akan pernah ada pembelian perabotan rumah yang mewah. Dengan demikian, perlu dicatat sejak awal bahwa untuk mengangkat nilainilai pendidikan karakter dan kewirausahaan tidak diukur dari kekayaan yang mereka dapat kumpulkan, tetapi harus berdasarkan pada nilai-nilai luhur yang ajarkan kepada anakanak mereka.

\section{Simpulan dan Saran}

Proses adaptasi nilai-nilai karakter dan kewirausahaan yang terdapat di kampung adat secara umum cukup banyak memiliki nilai-nilai budaya yang dapat diintegrasikan pada proses pembelajaran. Nilai-nilai seperti nilai mandiri, kreatif, berani mengambil risiko, berorientasi pada tindakan, kepemimpinan, dan kerja keras terlihat pada setiap aspek aktivitas yang dilaksanakan oleh warga yang ada di kampung adat. mengembangkan nilai-nilai karakter dan kewirausahaan yang semakin kuat, maka peserta didik dapat pula mengenal nilai-nilai kearifan lokalnya.

Perangkat pembelajaran, mulai dari RPP, media pembelajaran, alat penilaian pada 4 mata pelajaran, yaitu IPA, IPS, Matematika, dan Bahasa Indonesia. Keempat mata pelajaran ini dikembangkan sesuai dengan penerapan kurikulum 2013 yaitu dengan menggunakan pendekatan saintifik, dan tematik integratif. Melalui perangkat pembelajaran ini, nilai-nilai kearifan lokal dimasukkan dalam proses pembelajaran. Implementasi model pendidikan karakter dan kewirausahaan berbasis etnopedagogis di SD secara umum efektif. Hal ini dibuktikan dengan hasil belajar siswa yang semakin baik, antusiasme siswa dalam belajar semakin tinggi, serta keaktifan siswa dalam belajar pun lebih meningkat. Hal ini ditunjukkan dengan berbagai aktivitas yang sudah disiapkan oleh guru dijalani dengan menyenangkan oleh para siswa.

Saran yang dapat diajukan adalah bahwa kita perlu terus dikembangkan secara lebih aplikatif sehingga memadukan antara budaya (yang baik) di lingkungan masyarakat setempat dengan karakter bangsa yang diajarkan sekolah lebih sistematis dan terarah. 
Hal ini akan dilakukan pada uji coba tahun berikutnya.Untuk mendukung keterlaksanaan pendidikan budaya dan karakter bangsa yang mencerminkan kehidupan nilai-nilai budaya dan karakter bangsa yang diinginkan perlu ada komunikasi yang lebih intensif antara pihak sekolah dengan komunitas masyarakat setempat sehingga kedua belah pihak bisa saling melengkapi.

\section{Daftar Pustaka}

Dewi, Laksmi dkk. (2015). Nilai Karakter Kampung Adat dalam Pengembangan Pendidikan Karakter dan Kewirausahaan berbasis Etnopedagogis di Sekolah Dasar. Prosiding: Seminar dan Temu Akademisi PLS Tingkat Nasional. ISBN: 978-60217016-4-5.

Hakim, Dhikrul. (2012).Pengembangan Pendidikan Kewirausahaan Berdasarkan Nilai-Nilai Budaya Untuk Membentuk Daya Saing Dan Karakter Bangsa. Tersedia pada Iaman file:///C:/Users/INNOVATION/ Downloads/179-332-1-PB.pdf. [Online] diunduh tanggal 20-03-2014

Kemdikbud (2010). Panduan Bahan Pelatihan Pendidikan Kewirausahaan. Jakarta: Puskurbuk.

Koesoema, A. Doni. (2012). Pendidikan Karakter Utuh dan Menyeluruh. Yogyakarta: Kanisius.

Kompasiana. (2014). Utang Pemerintahan SBY selama 9 Tahun Rp 1.496,12 Triliun, Mengapa Rakyat Jelata Makin Susah Hidupnya?. Tersedia pada laman http:// www.kompasiana.com/musniumar/utangpemerintahan-sby-selama-9-tahun-rp1-496-12-triliun-mengapa-rakyat-jelatamakin-susah-hidupnya_5528751b6ea83 4b8418b459b. Diunduh pada 26-06-2015

Qodar, Nafiysul Qodar. (2015), 15 Mar 2015 at 01:05 WIB). Survei ICRW: 84\% Anak Indonesia Alami Kekerasan di Sekolah. Tersedia pada laman http://news. liputan6. com/read/2191106/survei-icrw-84-anakindonesia-alami-kekerasan-di-sekolah. Diunduh tanggal 26-06-2015.

Susanti, L.R Retno. (2011). Membangun pendidikan karakter di sekolah :Melalui Kearifan Lokal. Makalah Disampaikan pada Persidangan.

Susilowati, Tutik; Susantiningrum. (2013). Pengembangan Pendidikan Kewirausahaan Dalam Upaya Menumbuhkan Budayawirausaha Pada Siswa Sekolah Menengah Atas (SMK) Di Kabupaten Karanganyar. Jurnal: JKB No. 12. Th.VII.
Januari 2013.

Sumardiningsih, Sri; Mulyani, Endang; Supardi. (.......). Pengembangan Model Pengintegrasian Pendidikan Karakter Dan Pendidikan Kewirausahaan Dalam Pembelajaran Di Smk Daerah Istimewa Yogyakarta. tersedia pada laman http://staff.uny.ac.id/sites/default/ files/penelitian/Dr.\%20Endang\%20 Mulyani, \%20M.Si./Pengemb\%20 Model\%20Pengintegrasian\%20 Penddkn\%20Karakter\%20\&\%20KWU. pdf. [online] Diunduh tanggal 26-06-2015.

Syarbini, Amirulloh.(2012). Buku Pintar Pendidikan karakter. Panduan lengkap Mendidik Karakter Anak di Sekolah, Madrasah, dan Rumah. Jakarta: as@prima pustaka.

Utari, KS. (2006). Mengikis Ketidakadilan Gender Dalam Adat Bali. Makalah. Disajikan (untuk urun pendapat) dalam Temu Ilmiah II Asosiasi Pengajar dan Peminat Hukum Berspektif Gender se Indonesia (APPHGI). Tgl 18-20 September 2006, di Hotel Santika JIn Pandigiling 45 Surabaya Rosdakarya.

Wagiran. (2011). Pengembangan Model Pendidikan Kearifan Lokal di Wilayah Propinsi DIY dan Mendukung Perwujudan Visi Pembangunan DIY Menuju tahun 2025. Yogyakarta: Setda Provinsi DIY.

Wahyudin, Uyu. (2012). Pelatihan Kewirausahaan Berbasis Ekokultural untuk Pemberdayaan Masyarakat Miskin Pedesaan, Mimbar Jurnal Sosial dan Pembangunan UNISBA. Volume XXVIII Nomor 1 (Juni, 2012): $55-64$

Widodo, Slamet, taufik RDA Nugroho. (2014). Pendidikan Kewirausahaan bagi Santri: Sebuah Model untuk Mengatasi Pengangguran di Pedesaan, Mimbar Jurnal Sosial dan Pembangunan UNISBA, Volume 31 Nomor 2 (Desember 2014): 171 - 179

Yani, A. (2014). Mindset Kurikulum 2013. Bandung. CV. Alfabeta.

Zainudin, H.M; Mustofa, Hadi; Hakam, Dafid Sufyan. (2014). Membentuk Karakter Peduli Lingkungan dengan Model Pembelajaran Inkuiri, Mimbar Jurnal Sosial dan Pembangunan UNISBA, Volume 30, No. 1 (Juni, 2014); 11 - 17

Zuchdi, Darmiyati; Prasetya, Zuhdan Kun; Masruri, Muhsinatun Siasah. (2010). Pengembangan Model Pendidikan Karakter Terintegrasi Dalam Pembelajaran Bidang Studi Di Sekolah Dasar. Jurnal: Cakrawala Pendidikan, Mei 2010, Th. XXIX, Edisi Khusus Dies Natalis UNY. 